\title{
20. OCCURRENCE OF METHANE HYDRATES OFFSHORE SOUTHERN MEXICO ${ }^{1}$
}

\author{
Thomas H. Shipley, Scripps Institution of Oceanography, University of California at San Diego, La Jolla, California \\ and \\ Borys M. Didyk, Research and Development Laboratory, Empresa Nacional del Petroleo, Concon, Chile
}

\begin{abstract}
Evidence for naturally occurring methane hydrates was collected at three drill sites off the southern Mexico continental margin. The hydrates are manifested either by ice inclusions or, more often, as frozen porous volcanic ash and fine sands interlayered with muds. Gas generation from the ice inclusions and interstitial water of the frozen sediment was as high as about $7 \mathrm{ml}$ of gas $/ \mathrm{ml}$ of water. One large sample immediately placed in a sealed container released about $20 \mathrm{ml}$ of gas $/ \mathrm{ml}$ of water. All of these values are higher than may be accounted for by gas solubility at in situ conditions.

Measured thermal gradients place the bottom-simulating reflection (BSR) in this area very near the phase boundary for the methane hydrate system. This is consistent with earlier interpretations that the BSR is related to the hydrate/gas phase boundary.
\end{abstract}

\section{INTRODUCTION}

On DSDP Leg 66 during drilling on the Mexican continental margin southwest of Acapulco we recovered the first quantitative evidence for naturally occurring deep sea gas hydrates at three different drill sites. Gas hydrate (clathrate) compounds occur at elevated pressures and gas concentrations. These adduction compounds have an ice-like crystalline structure in which the gas molecules are physically trapped by the water molecule lattice. Naturally occurring gas hydrates have been observed in high pressure gas pipe lines (Hammerschmidt, 1940; Deaton and Frost, 1948), in permafrost regions of Siberia, in drilling in the MacKenzie Delta (Bily and Dick, 1974), and in drilling along the Middle America Trench (Leg 67, von Huene et al., 1980).

A number of marine seismic reflection studies have suggested the presence of gas hydrates in seafloor sediments (e.g., Bryan, 1974; Dillon et al., 1980; Shipley et al., 1979; Tucholke et al., 1977; White, 1979). The recognition of natural gas hydrates is increasing rapidly and has been recently reviewed by Kvenvolden and McMenamin (1980).

Naturally occurring methane hydrate is an interesting substance because it may contain up to $170 \mathrm{ml}$ of methane per milliliter of interstitial water. Also, completely gas-hydrated sediments might result in reduced permeability and permit gas and oil accumulation below a hydrate cap. Thus, knowledge of these substances and their possible presence in marine sediments is important for evaluating their potential as an energy resource and for drilling safety and pollution prevention.

\section{VISUAL AND GEOCHEMICAL OBSERVATIONS}

Evidence for the presence of gas hydrates in sediments has come mostly from indirect measurements or observations. Commonly cited evidence for the exis-

\footnotetext{
1 Initial Reports of the Deep Sea Drilling Project, Volume 66.
}

tence of gas hydrates comes from gas-charged sediments in areas of gas hydrate stability and from high gas content in drilling muds and in retrieved samples, or from logging interpretations and seismic evidence for some bottom-simulating reflectors (BSR).

On Leg 66, drilling recovered ice inclusions and frozen sediments which released large quantities of gas. These frozen sediments and ice inclusions are believed to be hydrates or to be related to in situ hydrated sediments. The ice inclusions and frozen zones were initially detected in soft sediments as cores were being split with a thin wire. The frozen intervals were difficult or impossible to split and resulted in considerable core disturbance. We began systematically inspecting the exterior of the core liners for cold areas in order to open suspect cores earlier than normal, often within $15 \mathrm{~min}$. after arrival on deck, versus 1 to $4 \mathrm{hr}$. as in the normal operation. Even so, it is likely that some zones of concentrated gas hydrate material were not detected. Gas hydrates will remain stable during the drilling processes because the hole is flushed with cold $\left(\sim 0^{\circ} \mathrm{C}\right)$ seawater. During retrieval of the core, gas hydrates would continue to be stable until about $200-300$ meters below the ship, where the pressure becomes low enough and temperature high enough to cause instability. In all, nine zones from three different holes $(490,491$, and 492 , Table 1) were suspected to have contained gas hydrates. The zones are grouped into two types of occurrences.

\section{Ice Inclusions}

The first type, comprising Samples 1, 5, and 7 (Table 1), consist of frozen materials which were impure ice, up to $2 \mathrm{~cm}$ in diameter in voids of the core or in expansion zones of the unconsolidated mud. These ice inclusions bubbled releasing gas and upon melting were found to consist basically of seawater with minor amounts of sediments. Typically, upon splitting a core (e.g., Core 15 , Hole 490, from a sub-bottom depth of $139 \mathrm{~m}$; Figs. 1 and 2), gas-releasing ice inclusions were observed in gas expansion voids. The ice in Core 15 released $0.91 \mathrm{ml}$ 
Table 1. Suspected gas hydrate occurrence on Leg 66.

\begin{tabular}{|c|c|c|c|c|c|c|c|c|c|c|c|c|c|c|c|c|}
\hline \multirow[b]{2}{*}{$\begin{array}{l}\text { Sample } \\
\text { No. }\end{array}$} & \multirow[b]{2}{*}{ Hole } & \multirow{2}{*}{$\begin{array}{l}\text { Water } \\
\text { Depth } \\
\text { (m) }\end{array}$} & \multirow{2}{*}{$\begin{array}{l}\text { Sub-bottom } \\
\text { Depth } \\
\text { (m) }\end{array}$} & \multirow[b]{2}{*}{ Lithology/Comments } & \multicolumn{2}{|c|}{ Estimated In Situ } & \multicolumn{2}{|c|}{$\begin{array}{l}\text { Hydrate } \\
\text { Gas-generating } \\
\text { Ratio }^{\mathrm{c}}\end{array}$} & \multirow[b]{2}{*}{$\begin{array}{l}\mathrm{CO}_{2} \\
(\%)\end{array}$} & \multirow[b]{2}{*}{$\begin{array}{l}\mathrm{C}_{1} \\
(\%)\end{array}$} & \multirow[b]{2}{*}{$\begin{array}{l}\mathrm{C}_{2} \\
(\%)\end{array}$} & \multirow[b]{2}{*}{$\underset{(\mathrm{ppm})}{\mathrm{C}_{3}}$} & \multirow[b]{2}{*}{$\underset{(\mathrm{ppm})}{\mathrm{C}_{4}}$} & \multirow[b]{2}{*}{$\underset{(\mathrm{ppm})}{\mathrm{C}_{5}}$} & \multirow[b]{2}{*}{$\mathrm{C}_{1} /\left(\mathrm{C}_{2}+\mathrm{C}_{3}\right)$} & \multirow[b]{2}{*}{ Gas $^{\mathrm{d}}$} \\
\hline & & & & & $\begin{array}{l}\text { Pressure }^{\mathrm{a}} \\
\text { (atm) }\end{array}$ & $\begin{array}{l}\text { Temperature }{ }^{\mathrm{b}} \\
\left({ }^{\circ} \mathrm{C}\right)\end{array}$ & Measured & $\begin{array}{l}\text { Porosity } \\
\text { Corrected }\end{array}$ & & & & & & & & \\
\hline 1 & 490 & 1761 & $139.73-139.75$ & $\begin{array}{l}\text { Ice Inclusion } \\
\text { Ice inclusions in mud near } \\
\text { large wood fragment (Fig. 2) }\end{array}$ & 190 & 6 & 0.91 & 0.91 & 23.23 & 76.77 & $n a^{e}$ & $n a$ & $n a$ & $n a$ & $n a$ & $\begin{array}{l}\text { Gas released by ice } \\
\text { inclusion }\end{array}$ \\
\hline 2 & & & $145.40-145.75$ & $\begin{array}{l}\text { Frozen Sediment } \\
\text { Frozen muddy to silty lami- } \\
\text { nated volcanic ash }\end{array}$ & 190 & 6 & & & 3.00 & 97.00 & na & na & na & na & na & $\begin{array}{l}\text { Gas from core liner } 0.45 \mathrm{~m} \\
\text { above frozen material }\end{array}$ \\
\hline 3 & & & $166.50-166.85$ & $\begin{array}{l}\text { Frozen Sediment } \\
\text { Frozen sandy to silty lami- } \\
\text { nated ash layer, temperature } \\
-2^{\circ} \text { to }-0.8^{\circ} \mathrm{C} \text {. }\end{array}$ & 195 & 7 & & & 1.56 & 98.19 & 0.25 & 11 & 8 & 3 & 376 & $\begin{array}{l}\text { Gas from core liner } 0.25 \mathrm{~m} \\
\text { below frozen material }\end{array}$ \\
\hline 4 & & & $364.00-364.50$ & $\begin{array}{l}\text { Frozen Sediment } \\
\text { Frozen bioturbated (mixed) } \\
\text { mudstone and clayey ash, } \\
\text { temperature } 1.7^{\circ} \mathrm{C} 2 \mathrm{hr} \text {. } \\
\text { after core on deck }\end{array}$ & 210 & 11 & & & 0.47 & 99.21 & 0.26 & 249 & 217 & 34 & 348 & $\begin{array}{l}\text { Gas from core line } 0.30 \mathrm{~m} \\
\text { above frozen material }\end{array}$ \\
\hline 5 & 491 & 2883 & $88.90-89.00$ & $\begin{array}{l}\text { Ice Inclusion } \\
\text { Ice blebs in mud (Fig. 1) }\end{array}$ & 295 & 4 & 7.22 & 7.22 & 1.62 & 98.34 & 0.03 & 55 & 42 & 22 & 2809 & $\begin{array}{l}\text { Gas from core liner } 2.00 \mathrm{~m} \\
\text { below ice inclusion }\end{array}$ \\
\hline 6 & & & $162.70-163.15$ & $\begin{array}{l}\text { Frozen Sediment } \\
\text { Frozen bubbling fine sand } \\
\text { beds }(10 \mathrm{~cm} \text { and } 15 \mathrm{~cm}) \text {, } \\
\text { temperature } 1 \text { to } 1.5^{\circ} \mathrm{C}\end{array}$ & 305 & 6 & & & 0.73 & 99.18 & 0.08 & 37 & 12 & 8 & 1180 & $\begin{array}{l}\text { Gas from core liner } 5.00 \mathrm{~m} \\
\text { above frozen material }\end{array}$ \\
\hline 7 & & & $168.30-168.35$ & $\begin{array}{l}\text { Ice Inclusion } \\
\text { Frozen mud and ice }\end{array}$ & 305 & 6 & 0.02 & 0.02 & 0.79 & 98.27 & 0.89 & 478 & 194 & 110 & 100 & $\begin{array}{l}\text { Gas from core liner } 4.10 \mathrm{~m} \\
\text { below frozen material }\end{array}$ \\
\hline 8 & 492 & 1935 & $140.95-141.10$ & $\begin{array}{l}\text { Frozen Sediment } \\
\text { Frozen muddy laminated } \\
\text { volcanic ash layer (Figs. } 3 \\
\text { and 4) }\end{array}$ & 205 & 6 & 3.26 & 7.09 & 0.22 & 99.59 & 0.18 & 50 & 47 & nd & 1200 & $\begin{array}{l}\text { Gas relased by frozen } \\
\text { sediment }\end{array}$ \\
\hline 9 & & & $169.50-169.57$ & $\begin{array}{l}\text { Frozen Sediment } \\
\text { Frozen muddy laminated } \\
\text { volcanic ash, temperature } \\
0.8^{\circ} \mathrm{C}\end{array}$ & 210 & 6 & $\begin{array}{l}2.16 \\
9.4\end{array}$ & $\begin{array}{l}4.70 \\
20.4\end{array}$ & 0.23 & 99.68 & 0.08 & 34 & 37 & nd & 1200 & $\begin{array}{l}\text { Gas released by frozen } \\
\text { sediment }\end{array}$ \\
\hline
\end{tabular}

${ }^{\text {a }}$ Minimum estimated from hydrostatic gradient $99.7 \mathrm{~atm} / \mathrm{km}$ water and $0.1 \mathrm{~atm} / \mathrm{m}$ sediments.

Estimated from measured hottom water temperatures and a gradient $2.2 \% 100 \mathrm{~m}$ (Shipley and Shephard, this volume).

$\mathrm{ml} \mathrm{gas} / \mathrm{ml}$ sample, porosity correction $(46 \%)$ is assumed for frozen sediments to correct to $\mathrm{ml}$ gas $/ \mathrm{ml}$ water in inferstial water.

Gas composition corrected for air components.

$\mathrm{e} \mathrm{na}=\mathrm{Not}$ analyzed. nd $=$ not detected. $\mathrm{H}_{2} \mathrm{~S}$ was not detected in any of the samples. 


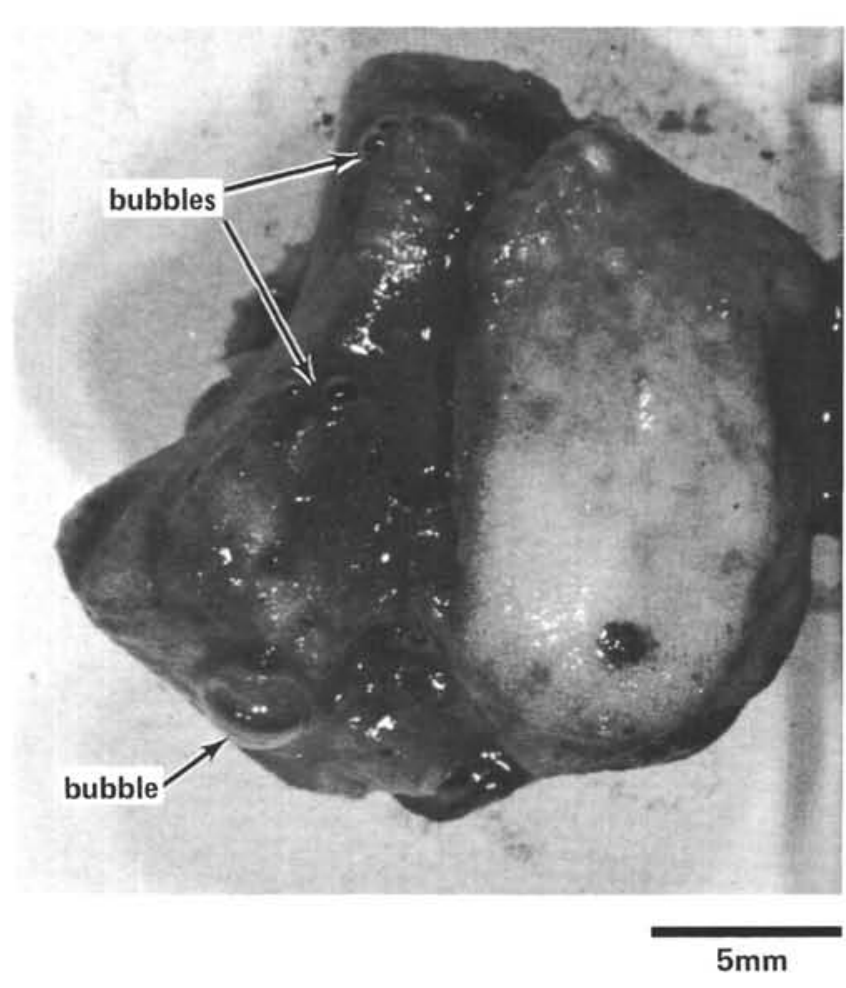

Figure 1. Ice inclusion from Hole 491, Core 10, at a sub-bottom depth of 89.0 meters. Note bubbles as sample degasses. (Bar is $5 \mathrm{~mm}$.)

gas/ml of ice (a gas-generating ratio [GGR] of 0.91). The gases consisted of $76.8 \%$ methane and $23.2 \% \mathrm{CO}_{2}$. Similar gas-releasing ice inclusions were observed in Hole 491, Samples 5 and 7 (Table 1) with gas-generating ratios of 7.22 and 0.02 , respectively.

The amount of gas released by the ice in Hole 490, Sample 1, is not significantly higher than the gas released by a sample of in situ interstitial water $0.47 \mathrm{ml}$ gas $/ \mathrm{ml} \mathrm{H}_{2} \mathrm{O}\left(87.1 \%\right.$ methane, $\left.12.9 \% \mathrm{CO}_{2}\right)$ retrieved from the same hole at a sub-bottom depth of 189.5 meters (see site chapter). Degasification by high-speed blending of a sediment sample collected from the same hole at a sub-bottom depth of 155 meters released 0.04 $\mathrm{ml}$ gas $/ \mathrm{ml}$ sediment ( $74.6 \%$ methane, $25.3 \% \mathrm{CO}_{2}$ ).

It is not clear if these ice inclusions represent actual hydrates or water incorporated into expansion voids which were subsequently frozen by hydrate sublimation during retrieval. Temperatures measured on deck were lower than the estimated in situ conditions. The cooling could have originated in response to a phase change associated with the decomposition of hydrates in the vicinity or by degassing and expansion of the gas released by the sediments during drilling and retrieval.

\section{Frozen Sediments}

The more common occurrence of gas-releasing materials in Leg 66 samples are frozen sediments containing predominantly porous volcanic ash and fine sands. Frozen sediments were observed in six cases (Table 1), always in unlithified sediments. Perfectly preserved structures, such as a color-banded frozen volcanic ash shown

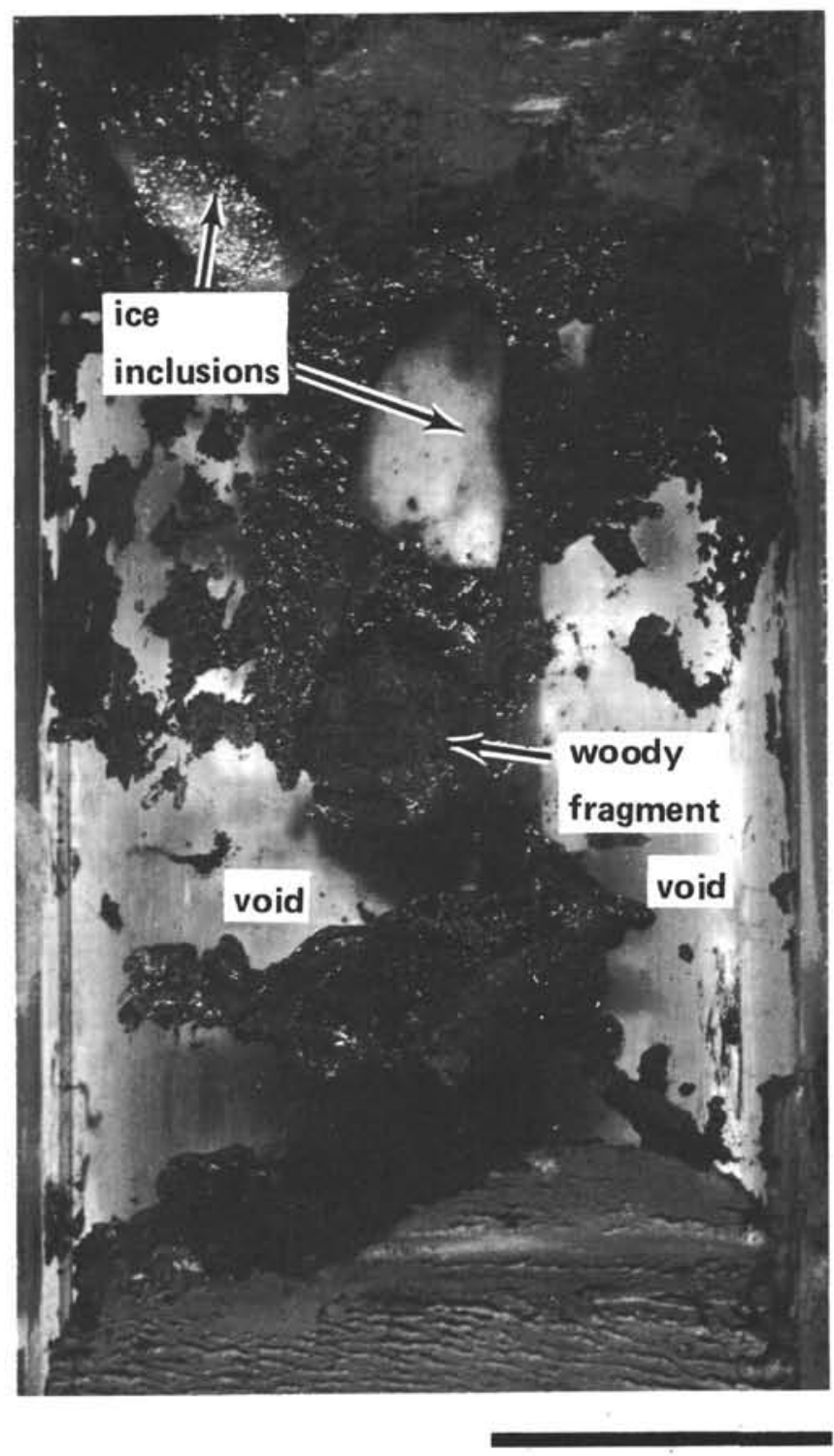

$3 \mathrm{~cm}$

Figure 2. Ice inclusions from Hole 490 , Core 15 , at a sub-bottom depth of 139.7 meters.

in Figures 3 and 4, were common. On equilibration to room temperature, these frozen sediments lost rigidity, structures were destroyed, and the samples ended up as swirled, structureless lumps of wet sediment.

Upon splitting Core 16, Hole 492 (sub-bottom depth of $140.95 \mathrm{~m}$ ), a gas-releasing laminated ash section of about $10 \mathrm{~cm}$ was observed (Fig. 4). This sample (Table 1, No. 8) was found to release $3.26 \mathrm{ml}$ of gas $/ \mathrm{ml}$ of frozen sediment and consist of $99.5 \%$ methane, $0.22 \%$ $\mathrm{CO}_{2}, 0.18 \%$ ethane, and traces of $\mathrm{C}_{3}$ and $\mathrm{C}_{4}(50$ and 47 $\mathrm{ppm}$, respectively). This was similar in composition to the gas retrieved from the core liner close to $140.45 \mathrm{me}-$ ters sub-bottom, consisting of $99.43 \%$ methane, $0.28 \%$ $\mathrm{CO}_{2}, 0.28 \% \mathrm{C}_{2}$, and traces of $\mathrm{C}_{3}, \mathrm{C}_{4}$, and $\mathrm{C}_{5}(30,26$, and $5 \mathrm{ppm}$, respectively). The gas found in the liner during core retrieval may have been liberated by sublimation of gas hydrate. 


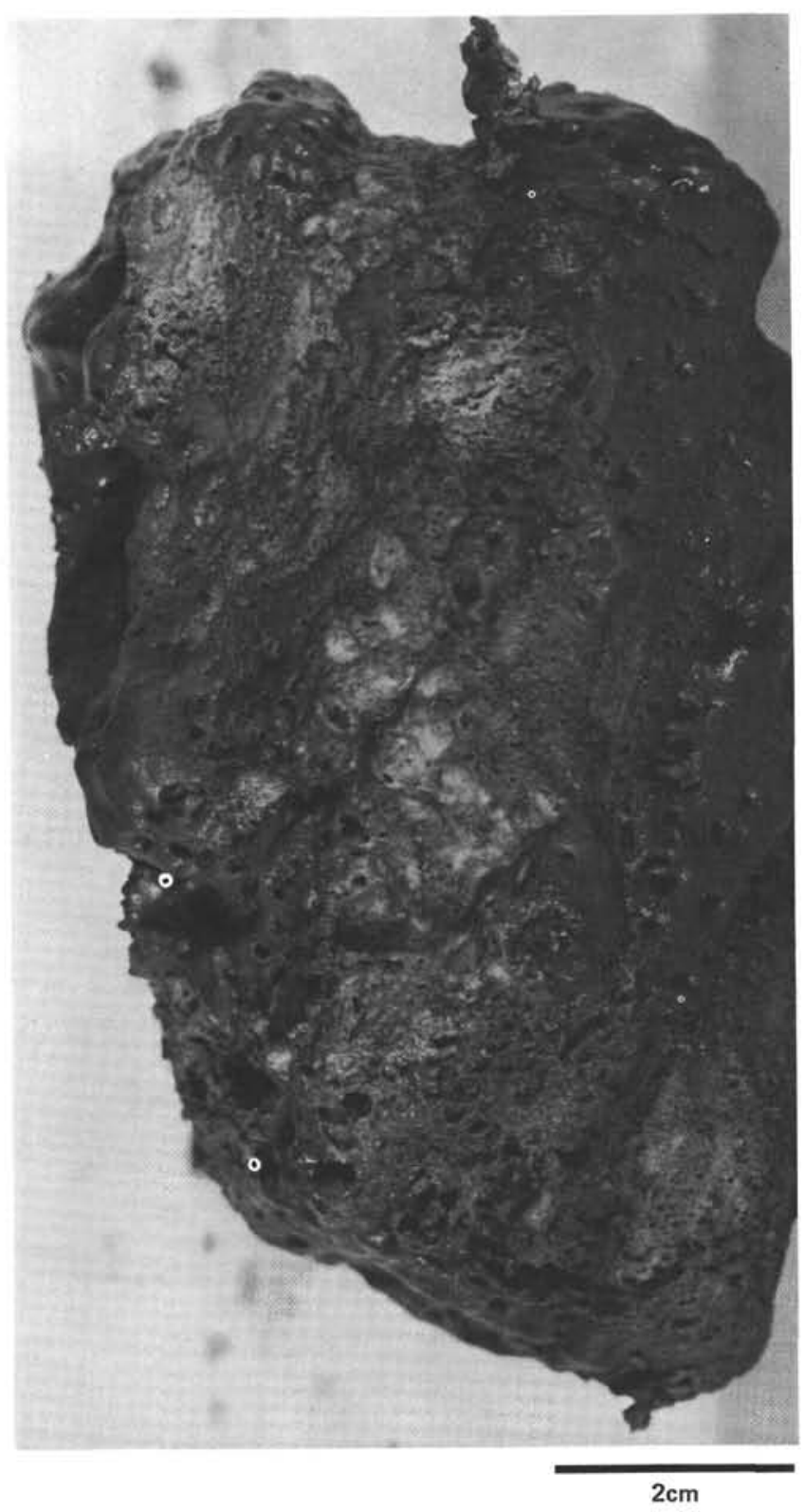

Figure 3. Frozen white gray and black-banded volcanic ash layer from Hole 492, Core 16.

Similar gas-releasing frozen sediment inclusions were observed in Hole 490, Samples 2, 3, and 4; Hole 491, Sample 6; and Hole 492, Sample 9. Similarly the gases consisted mainly of methane $\geq 97 \%$, with minor amounts of $\mathrm{CO}_{2}$, ethane, and traces of higher hydrocarbons $\mathrm{C}_{3}$ to $\mathrm{C}_{5}$ (Table 1). Because of the operational conditions prevailing during drilling, core retrieval, and sampling, it is difficult to establish the in situ amount of gas originally present in the undisturbed formation. The cored sediment samples will adjust their gas content in response to decreasing pressure and temperature changes produced during drilling, retrieval, and core sampling. Thus the volumes of gas released by the frozen sediments after sampling on deck are probably lower than the in situ gas content.

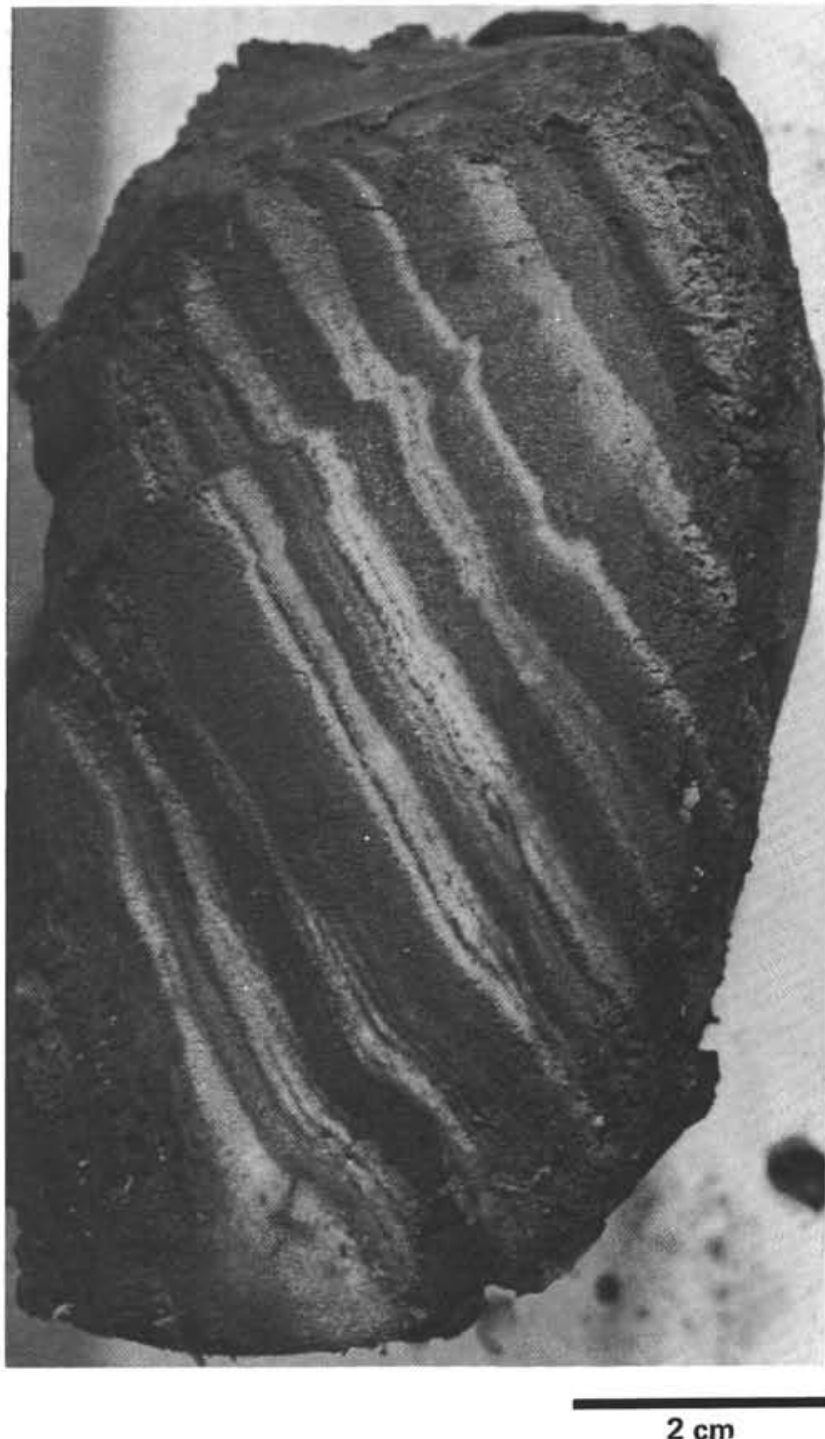

Figure 4. Same sample as in Figure 3 except that the ash layer has been sliced in half to show the structures. Upon sublimation a wet, soupy sediment was formed and the original lamination badly disturbed.

The amount of gas released by the frozen samples after removal from the split cores varied by two orders of magnitude, ranging from 0.02 to $9.40 \mathrm{ml}$ gas $/ \mathrm{ml}$ frozen material. In the ice inclusions the highest observed gas content was $7.22 \mathrm{ml}$ gas/ml ice, which consisted predominantly of ice $>90 \%$ with minor amounts of included sediments. The frozen sediments generally show lower gas contents. The highest observed value was 3.26 $\mathrm{ml}$ gas $/ \mathrm{ml}$ frozen material for Sample 8. If the amount of gas in this sample is corrected for porosity (about $46 \%$ and assuming that no gas is adsorbed on the volcanic ash), a gas content of $7.18 \mathrm{ml}$ gas $/ \mathrm{ml}$ can be estimated for the associated interstitial water. One large sample from Hole 492, Core 19 core catcher, at a subbottom depth of 169.5 meters, was trimmed and placed in a sealed pressure vessel. During sublimation, $9.4 \mathrm{ml}$ of gas $/ \mathrm{ml}$ of sediment was released. With the porosity 
correction $(46 \%)$, the GGR of the interstitial water is about 20 . This is the highest value obtained for any Leg 66 samples.

With the exception of the one GGR of 20, the highest gas content from either the interstitial water of the frozen sediments or from the ice inclusions is about $7 \mathrm{ml}$ gas $/ \mathrm{ml}$ water. This is twice the volume of gas that can be dissolved in water in the absence of hydrates at elevated pressures ( 6 times for the sample with a GGR of 20), suggesting the excess gas was accommodated in a gas hydrate.

\section{In Situ Pressure and Temperature}

We determined the in situ pressure and temperature conditions to verify that gas hydrates would be stable at the depths from which the samples were recovered. The in situ pressure was estimated from the hydrostatic gradient (99.7 atm $/ \mathrm{km}$ of seawater) and a minimum geostatic gradient of $0.1 \mathrm{~atm} / \mathrm{m}$ for the sediments. Total confining pressures ranged from about 190 to 305 atm (Table 1). Despite numerous attempts to measure the in situ temperature using the Uyeda temperature probe, the results were mixed. Shipley and Shephard (this volume) reviewed all the temperature data and estimated a gradient at $2.2^{\circ} \mathrm{C} / 100 \mathrm{~m}$ for the margin. Using this gradient with bottom water temperature measurements from the Uyeda probe gave in situ temperatures ranging from about 4.3 to about $11.1^{\circ} \mathrm{C}$.

The ranges in pressure and temperature conditions for the recovered frozen samples along the Mexico drilling transect are plotted on a phase diagram in Figure 5 and fall in all cases well within the methane hydrate stability field.

\section{Discussion}

The gas released by the frozen hydrated material was similar in composition to the gas which had been recovered from the core liner in their close vicinity. These gases consisted primarily of methane (98.3-99.7\%) with minor amounts of $\mathrm{CO}_{2}(0.2-1.6 \%)$ and ethane $(0.03-$ $0.2 \%$ ) (Table 1 ). Higher hydrocarbons $\mathrm{C}_{3}, \mathrm{C}_{4}$, and $\mathrm{C}_{5}$ were also detected in small amounts, at ppm levels.

The origin of hydrocarbon gases recovered from sediments has been correlated with their composition and stable carbon isotope distributions (Bernard et al., 1977; Claypool et al., 1980). In gases recovered from Gulf of Mexico sediments, the presence of significantly increasing quantities of heavier hydrocarbons $\mathrm{C}_{1} /\left(\mathrm{C}_{2}+\mathrm{C}_{3}\right)$ $<50$ is associated with a petrogenic origin, whereas leaner gases $C_{1} /\left(C_{2}+C_{3}\right)>1000$ are associated with a biogenic origin (Bernard et al., 1977). It is also postulated that during upward migration in unconsolidated sediments, petrogenic gases may become depleted of higher hydrocarbons, thus resembling a leaner biogenic gas, or become diluted by biogenic gas with a consequent increase in the $\mathrm{C}_{1} /\left(\mathrm{C}_{2}+\mathrm{C}_{3}\right)$ ratio (Bernard et al., 1977).

The overall $C_{1} /\left(C_{2}+C_{3}\right)$ ratios for the gases released by the hydrated materials, or the related core liner gases recovered during Leg 66, varied from 2809 to 105 (Table 1). Thus the relatively high ratios suggest that these

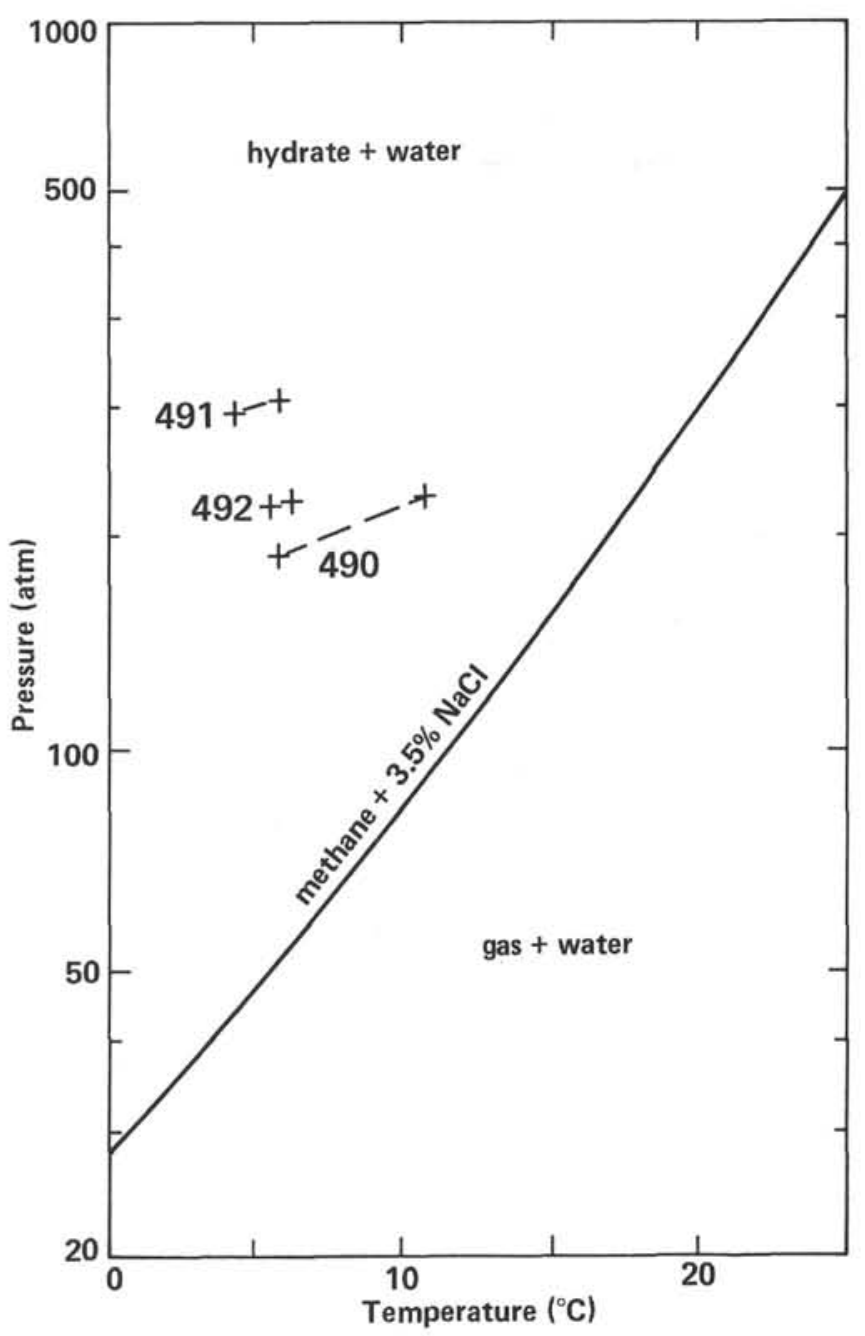

Figure 5. In situ pressure and temperature range for frozen samples collected on Leg 66.

gases are predominantly of a biogenic origin, even though deeper gases from Hole 491 showed a lower ratio that might suggest a partial petrogenic origin.

\section{SEISMIC REFLECTION DATA}

Seismic reflection evidence (Shipley et al., 1979) caused us to suspect the presence of gas hydrates along the Mexican margin, because high amplitude reflections, crossing other reflections and generally sub-parallel to the seafloor (the bottom-simulating reflector [BSR]) are observed here and have been reported to be related to gas hydrates on the Blake Outer Ridge along the U.S. east coast (Markl et al., 1970). Bryan (1974) suggested that the high amplitude of the BSR along portions of the Blake Outer Ridge may result from gas accumulation at the hydrated zones. Essentially, the hydrated sediments may reduce the permeability of the upper section, thus acting as a cap rock (Dillon et al., 1980). Tucholke et al. (1977) demonstrated that the BSR in the Blake Outer Ridge area lies close to the gas hydrate phase boundary. Many new areas of probable gas hydrate occurrence have been identified in seismic reflection data, which 
show that the BSRs have large reflection coefficients, a reversal in reflection polarity (indicating a reduction in velocity or density or both at the interface) and increasing sub-bottom depth with increasing water depth.

\section{Reflection Coefficients}

In an attempt to understand the changes in velocity and density at the BSR and distribution of gas hydrates, we made an estimate of the BSR reflection coefficients in an area off Mexico where the seafloor is nearly horizontal (see Shipley et al., 1979, for method). Averaging 14 shots, the reflection coefficient for the water bottom is $0.17 \pm 0.06$ and the hydrate $-0.08 \pm 0.03$. The coefficient for the hydrate falls between reported values for other areas of -0.05 to -0.012 (Table 2 ). This reflection coefficient allows us to estimate the density and velocity associated with the BSR. Substituting the velocity and density data from the lower part of Site 490 of $1.8 \mathrm{~km} / \mathrm{s}$ and $1.9 \mathrm{~g} / \mathrm{cc}$ (Shephard, this volume) in the equation impedance $=\left(\varrho_{2} \nu_{2}-\varrho_{1} \nu_{1}\right) /\left(\varrho_{2} \nu_{2}+\varrho_{1} \nu_{1}\right)$ results in $\varrho_{2} \nu_{2}$ equal to 2.4 . Presently we have no way to constrain the velocity or density function below the reflection other than to constrain the product of density and velocity (e.g., if $\nu_{2}=1.5$, then $\varrho_{2}=1.6$; if $\varrho_{2}=1.0$ then $\left.\nu_{2}=2.4\right)$. In this case, free gas is not required to account for the decrease in the velocity and/or density at this boundary.

\section{Velocity Structure}

Various estimates of velocities have been made which should indicate something about the concentrations of gas hydrates between the seafloor and the BSR. We are unable to use velocity data off Mexico because the section has been affected by tectonic deformation and dewatering. The relatively high velocities (about $2.1 \mathrm{~km} / \mathrm{s}$ ) probably reflect the effects of the accretionary process.

In a better-controlled case off the Blake Outer Ridge, independent velocity measurements range between 1.6 and $>2.5 \mathrm{~km} / \mathrm{s}$, with sonobuoy and multichannel reflection moveout methods clustering mainly between 1.6 and $1.9 \mathrm{~km} / \mathrm{s}$ (Table 3). The slope and rise province north of the Blake Outer Ridge have interval velocities of $2.0 \mathrm{~km} / \mathrm{s}$ for the upper 600 meters of section roughly corresponding to the same depth as the Blake Outer Ridge BSR (Houtz, 1980). Thus the observed velocities on the Blake Outer Ridge are not higher than in adjacent areas without BSRs. This suggests that either hydrated sediments are rather sparsely disseminated throughout the interval, concentrated in thin porous zones, or there is a gradient in the concentration, perhaps most concentrated only in a thin zone near the BSR

Table 2. Estimated reflection coefficients.

\begin{tabular}{lcccc}
\hline & $\begin{array}{c}\text { Water } \\
\text { Bottom }\end{array}$ & Hydrate & $\Delta \%$ & $\mathrm{~N}$ \\
\hline Blake Outer Ridge & $0.21 \pm 0.04$ & $-0.12 \pm 0.04$ & $-21 \pm 8$ & 13 \\
western Caribbean, Panama & $0.19 \pm 0.05$ & $-0.00 \pm 0.04$ & $-18 \pm 8$ & 11 \\
eastern Pacific, Panama & $0.18 \pm 0.02$ & $-0.05 \pm 0.03$ & $-10 \pm 6$ & 10 \\
eastern Pacific, Mexico & $0.17 \pm 0.06$ & $-0.08 \pm 0.03$ & $-14 \pm 5$ & 14 \\
\hline
\end{tabular}

Note: $\Delta \%$ is change in product of $\varrho \nu$ at the hydrate (BSR) reflection compared to the $e v$ of the overlying interval.
Table 3. Estimates of hydrated sediment velocities.

\begin{tabular}{|c|c|c|}
\hline Reference & $\mathrm{km} / \mathrm{s}$ & Method/Area \\
\hline Stoll et al., 1971 & $1.8-2.7$ & Laboratory experiment with coarse sand \\
\hline Hollister et al., 1972 & $2.0-2.2$ & $\begin{array}{l}\text { Drilling rate change on Blake Outer } \\
\text { Ridge associated with BSR }\end{array}$ \\
\hline Tucholke et al., 1977 & $1.6-1.9$ & $\begin{array}{l}\text { Wide-angle sonobuoy data from the } \\
\text { U.S. east coast and Blake Outer Ridge } \\
\text { associated with BSR }\end{array}$ \\
\hline \multirow[t]{3}{*}{ Shipley et al., 1979} & 1.7 & $\begin{array}{l}\text { Reflection moveout, Costa Rica, } \\
\text { Panama and Blake Outer Ridge } \\
\text { associated with BSR }\end{array}$ \\
\hline & 1.6 & $\begin{array}{l}\text { Reflection moveout from Nicaragua } \\
\text { associated with BSR }\end{array}$ \\
\hline & 2.1 & $\begin{array}{l}\text { Reflection moveout from Mexico } \\
\text { associated with BSR }\end{array}$ \\
\hline Dillon et al., 1980 & $>2.5$ & $\begin{array}{l}\text { Reflection moveout from Blake Outer } \\
\text { Ridge associated with BSR }\end{array}$ \\
\hline Houtz, 1980 & 1.9 & $\begin{array}{l}\text { Wide-angle sonobuoy data from Blake } \\
\text { Outer Ridge (interval velocity calculated } \\
\text { for } 600 \text {-meter section) }\end{array}$ \\
\hline
\end{tabular}

Note: Except for Stoll et al., 1971, velocities shown are interval velocities from the seafloor to the BSR. Higher velocity off Mexico attributed to dewatered and accreted sediments.

and thus not substantially affecting the average velocity of the interval. This is supported by the observation off Mexico that concentrated gas hydrates occurred in only a very small percentage of the cores, restricted to more porous layers.

We tend to believe the lower velocity function is most widely appropriate on the Blake Outer Ridge and that lower concentrations of hydrated sediments are thus the more normal case (as off Mexico). If velocities $>2.5$ $\mathrm{km} / \mathrm{s}$ were applicable to the whole Blake Outer Ridge, for example, the BSR would occur deeper in the section, with the temperature correspondingly higher by about $8^{\circ} \mathrm{C}$, putting the BSR well within the gas + water stability field (triangles would be displaced $8^{\circ} \mathrm{C}$ to right in Figure 6).

One disclaimer must be attached to the above discussion. Dillon et al. (1980) have reported fairly high velocities $(>2.5 \mathrm{~km} / \mathrm{s})$ for the seafloor to BSR interval in a portion of the Blake Outer Ridge (Table 3 ). This suggests that the concentration gradient may also vary laterally in response to other criteria not yet fully explained but perhaps related to gas-concentrating mechanisms.

\section{Thermal Gradient}

Prior to drilling off Mexico, the thermal gradient was estimated at $1.4^{\circ} \mathrm{C} / 100 \mathrm{~m}$ from very sparse surface heat flow data (Langseth and von Herzen, 1970). The P-T conditions at the BSR were then plotted on the phase diagram (Fig. 6). With the revised thermal gradient estimated at $2.2^{\circ} \mathrm{C} / 100 \mathrm{~m}$ from measurements conducted during the drilling operations (Shipley and Shephard, this volume), the Mexico BSR now is much closer to the methane hydrate/gas phase boundary and helps confirm the identification of this reflection as the base of hydrates. The small amounts of $\mathrm{CO}_{2}$ and ethane partially cancel the affect of salt on the system, with the pure methane gas/pure water phase boundary probably closely approximating the actual phase relationship. 


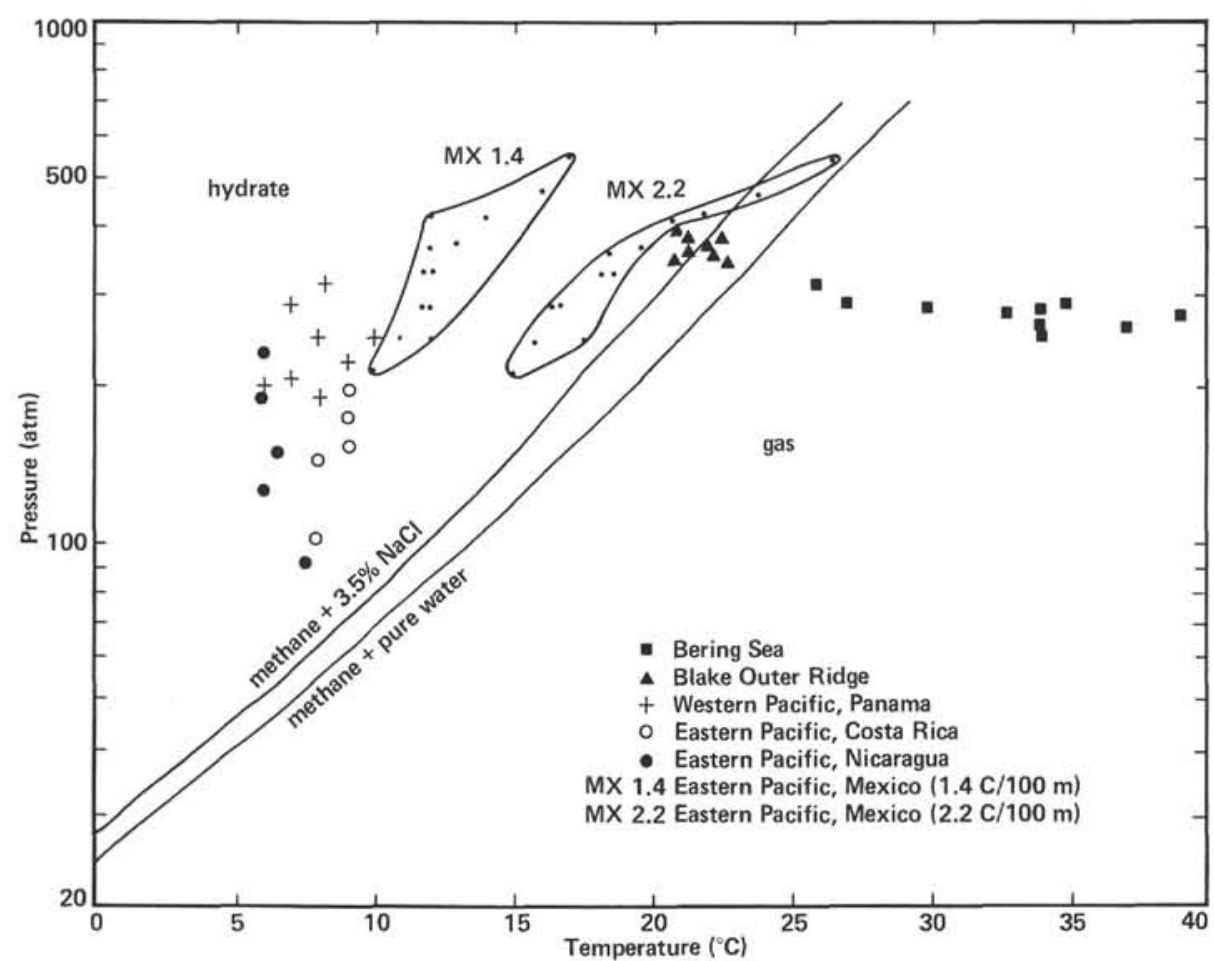

Figure 6. Pressure-temperature relationships for various BSRs. The MX 1.4 field are points plotted for the Mexico drilling data using published heat flow data. The points have been replotted with new gradient determined during the drilling program (MX 2.2). Bering Sea points are from an opal-A to -CT transformation BSR. Figure modified from Shipley et al. (1979).

\section{Distribution}

We have mapped the zone containing the basal hydrate reflection from the multichannel seismic reflection data in the Mexico survey area (Fig. 7). It occurs only over parts of the slope and is related (though imperfectly) to landward-dipping reflections along the inner wall of the trench (Fig. 8). Over most of the area, neither bedding reflections or basal hydrate reflections are observed (see Shipley, this volume). If any association exists between bedding and presence of the BSR, it may be related to significant grain-size differences which are needed to produce both reflections and avenues of gas migration. Shipley et al. (in press) have found a correlation between the occurrence of the landward-dipping reflections on the lower slope with submarine canyons feeding sands to the trench axis along the Middle America Trench. When these sands are accreted into the slope (otherwise predominantly muddy silt) they may provide the only stratigraphic avenues for concentration and migration of gas updip into the hydrate stability field in what are otherwise mud and muddy silt lithofacies. Gas concentration is more difficult where porous zones are absent.

Fundamentally, the occurence of the BSR may depend upon the possibility of transporting free gas up to the base of the hydrate zone, although small zones of hydrates produced by in situ gas production may exist in any case. Where migration avenues do not exist, there is probably insufficient gas concentration to develop the widespread hydrated zone required to produce a BSR.
Still, a basal reflection may form without sufficient gas migration avenues to produce a BSR as a response to uplift or rapid sedimentation which forces the phase boundary upward and releases in situ-produced gas trapped as gas hydrates.

\section{CONCLUSIONS}

Methane hydrate materials have been recovered during Leg 66 while drilling the upper part of the accretionary zone associated with the Middle America Trench off southwestern Mexico. These gas hydrates are located within unconsolidated sediments and were generally associated with porous zones of volcanic ash or sand layers, interbedded with mud or mudstone. The gases released by these hydrated materials are believed to be predominantly of a biogenic origin and to have originated in the unconsolidated sediments. The in situ pressure and temperature conditions calculated for the hydrate materials are consistent with the stability field of methane hydrates.

The gas hydrates were predominantly associated with porous and relatively uncompressible strata located within gas-containing compacting mud or mudstone sequences. These porous layers will collect and channel updip migrating compaction fluids composed of interstitial water containing dissolved gases of a biogenic and/or petrogenic origin. The emplacement of these fluids into parts of the sedimentary body where pressure and temperature conditions are consistent with hydrate formation and cause hydration. For the gases found offshore Mexico, hydrates could accommodate up to 


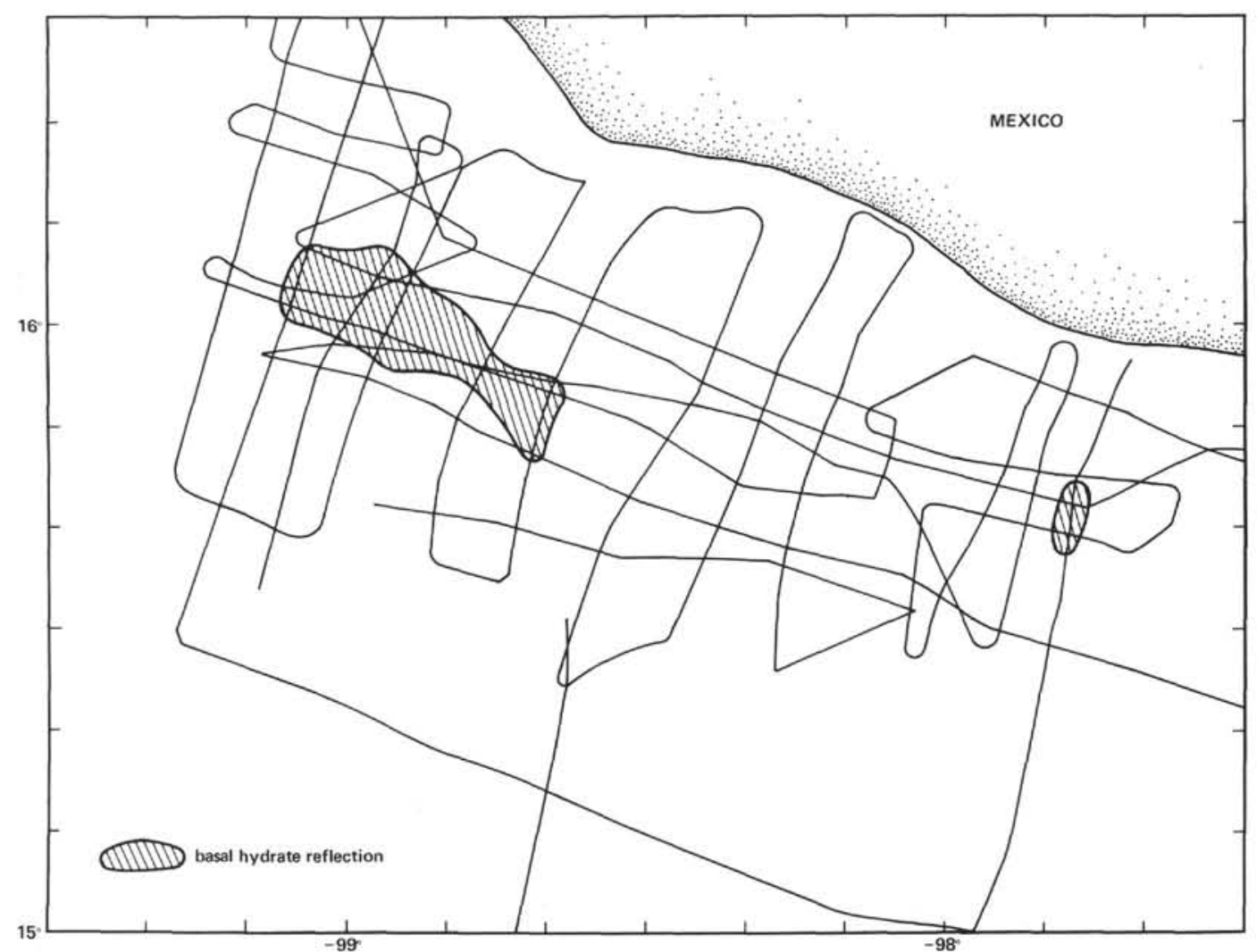

Figure 7. Distribution of BSRs off Mexico. Solid lines show distribution of multichannel profiles used to construct the map.

about 50 times more gas than could be incorporated in the same volume by simple solution. Thus hydration can generate a mechanism for concentration and accumulation of considerable amounts of biogenic gas at shallow sediment depths. Subsequent burial by sedimentation and/or relative uplift of the sedimentary units containing hydrates could change in situ pressure and temperature conditions with consequent hydrate decomposition, gas exsolution, and generation of shallow biogenic gas accumulations, if adequate reservoiring conditions are available. The phase change associated with decomposition of hydrates to free and dissolved gas could lead to the formation of overpressurized shallow gas accumulations, with consequent drilling safety risks, and could constitute an eventual gas resource located in immature sediments.

The occurrence of hydrated materials in this area is in agreement with the seismic reflection evidence of bottom-simulating reflectors which was previously interpreted as indicative of hydrate presence. The estimated in situ pressure and temperature at the bottom-simulating reflector are nearly coincident with the methane hydrate/gas and water phase boundary. The amounts of concentrated hydrates occuring in situ are apparently very small $(<<1 \%)$ and probably do not substantially affect the mean velocity or density structure of the sedimentary column except perhaps within $\sim 100$ meters above the BSR in a zone not penetrated on Leg 66.

\section{ACKNOWLEDGMENTS}

We thank B. Simoneit for reviewing this manuscript. Seismic data collection and processing was funded by National Science Foundation grants OCE76-2330 and NSF-IPOD contracts CU-TEX 25907-2-3.

\section{REFERENCES}

Bernard, B., Brooks, J. M., and Sackett, W. M., 1977. A geochemical model for characterization of hydrocarbon gas sources in marine sediments. Proc. 9th Annual Offshore Technology Conf., Houston, pp. 435-438.

Bily, C., and Dick, J. W. L., 1974. Naturally occurring gas hydrates in the MacKenzie Delta, N. W. T. Bull. Can. Petrol. Geol., 22: 320-352.

Bryan, G. M., 1974. In situ indications of gas hydrates. In Kaplan, I. R. (Ed.), Natural Gases in Marine Sediments: New York (Plenum), pp. 299-308.

Claypool, G. E., Threlkeld, C. H., and Magoon, L. B., 1980. Biogenic and thermogenic origins of natural gas in Cook Inlet Basin, Alaska. Am. Assoc. Petrol. Geol. Bull., 64:1131-1139.

Deaton, W. M., and Frost, E. M., Jr., 1948. Gas hydrates and their relation to the operation of natural-gas pipe lines. U.S. Bureau of Mines Monograph No. 8.

Dillon, W. P., Grow, J. A., and Paull, C. K., 1980. Unconventional gas hydrate seals may trap gas off southeast U.S. Oil \& Gas J., 78(1):124-130.

Hammerschmidt, E. G., 1940. Elimination of hydrate troubles. Oil \& Gas J., 39(2):61-68.

Houtz, R. E., 1980. Comparison of velocity-depth characteristics in western North Atlantic and Norwegian Sea sediments. J. Acoust. Soc. Am., 68:1409-1414.

Kvenvolden, K. A., and McMenamin, M. A., 1980. Hydrates of natural gas: A review of their geologic occurrence. U.S. Geol. Surv. Circular No. 825: Washington (U.S. Govt. Printing Office). 
Langseth, M. G., and Von Herzen, R. P., 1970. Heat flow through the floor of the world oceans. In Maxwell, A. E. (Ed.), The Sea (Vol. 4): New York (Wiley-Interscience), 299-352.

Markl, R. G., Bryan, G. M., and Ewing, J. I., 1970. Structure of the Blake-Bahama Outer Ridge. J. Geophys. Res., 75:4539-4555.

Shipboard Scientific Party, 1972. Sites 102, 103, 104-Blake-Bahama Outer Ridge (northern end). In Hollister, C. D., Ewing, J. I., et al., Init. Repts. DSDP, 11: Washington (U.S. Govt. Printing Office), 135-143.

Shipley, T. H., Houston, M. H., Buffler, R. T., et al., 1979. Seismic reflection evidence for the widespread occurrence of possible gashydrate horizons on continental slopes and rises. Am. Assoc. Pet. Geol. Bull., 63:2204-2213.
Shipley, T. H., Ladd, J. W., Buffler, R. T., et al., in press. Tectonic processes along the Middle America Trench inner slope. Geol. Soc. London Spec. Publ.

Stoll, R. D., Ewing, J. I., and Bryan, G. M., 1971. Anomalous wave velocities in sediments containing gas hydrates. J. Geophys. Res., 76:2090-2094.

Tucholke, B. E., Bryan, G. M., and Ewing, J. I., 1977. Gas-hydrate horizons detected in seismic-profiler data from the western North Atlantic. Am. Assoc. Petrol. Geol. Bull., 61:698-707.

von Huene, R., Aubouin, J., Azéma, J., et al., 1980. Leg 67, The Deep Sea Drilling Project, Mid-America Trench transect off Guatemala. Geol. Soc. Am. Bull., 91:421-432.

White, R. S., 1979. Gas hydrate layers trapping free gas in the Gulf of Oman. Earth Planet. Sci. Lett., 42:114-120.

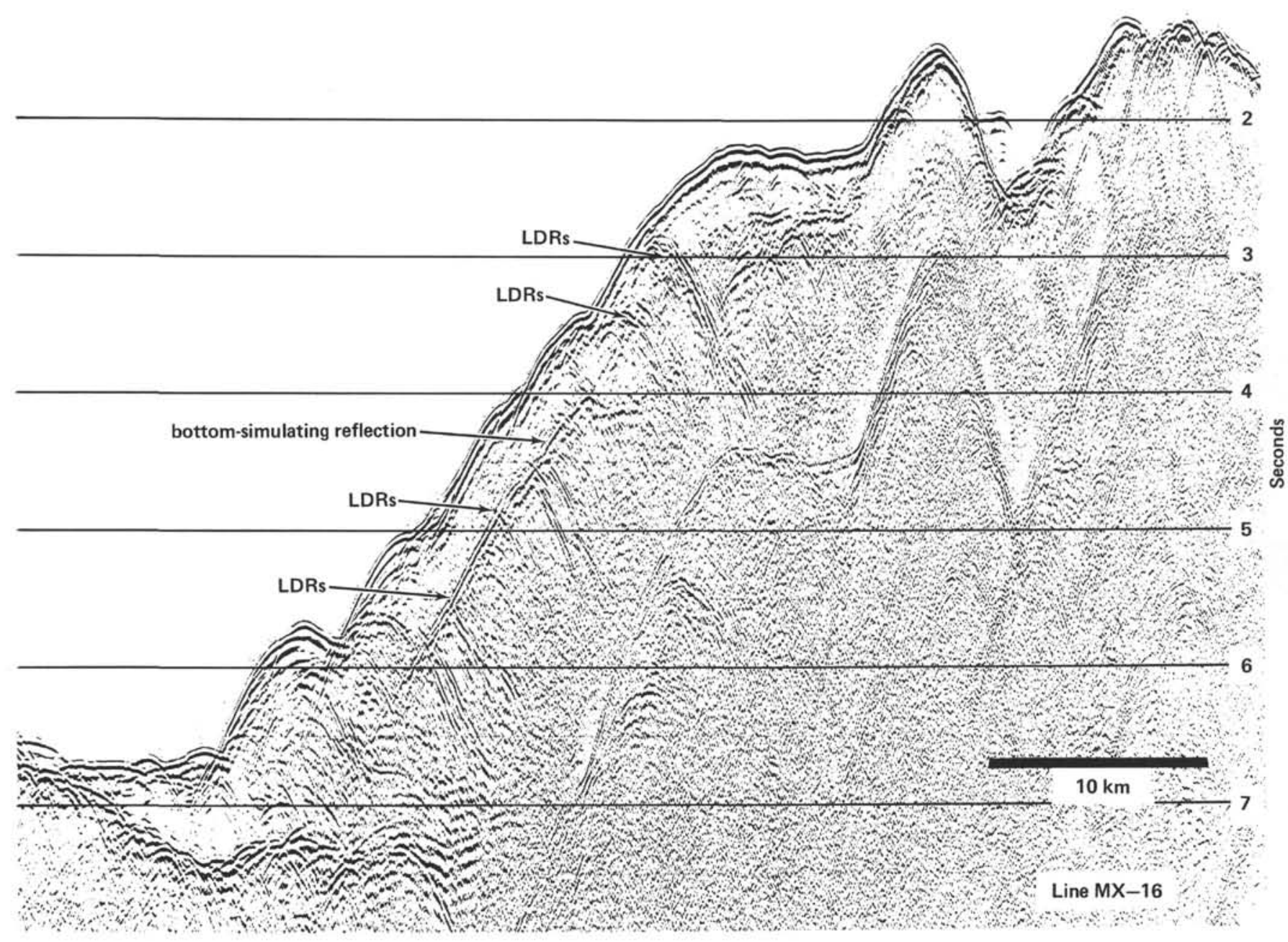

Figure 8. Migrated multichannel seismic section MX-16, showing the general relationship between the bottom-simulating reflection (BSR) and landward-dipping reflections (LDR). 